\title{
ADOPSI METODE DELONE DAN MCLEAN UNTUK MENGANALISIS FAKTOR FAKTOR KESUKSESAN IMPLEMENTASI SISTEM INFORMASI (STUDI KASUS : E-APBS DI KOTA PEKALONGAN)
}

\author{
Prastuti Sulistyorini ${ }^{1}$, Much. Rifqi Maulana ${ }^{2}$, Ichwan Kurniawan ${ }^{3}$ \\ STMIK Widya Pratama \\ ( $\underline{\text { sulistyorini72@gmail.com } 1}$, rifai@gmail.com ${ }^{2}$,ichwan.ana10@gmail.com ${ }^{3}$ )
}

\begin{abstract}
Abstrak
Tujuan utama dari penelitian ini adalah untuk menetapkan faktor - faktor yang mempengaruhi kesuksesan implementasi aplikasi e-APBS di Dinas Pendidikan Kota Pekalongan. Pembentukan aplikasi e-APBS telah menjadi sebuah kebutuhan yang penting bagi Dinas Pendidikan Kota Pekalongan, karena aplikasi e-APBS digunakan untuk mengelola rencana anggaran dan belanja sekolah dengan sumber dana bantuan dari pemerintah untuk operasional sekolah. Aplikasi e-APBS merupakan inovasi Dinas Pendidikan Kota Pekalongan untuk mewujudkan pengelolaan anggaran yang akuntabel, transparan dan efektif. Untuk mengetahui faktor-faktor kesusesan implementasi aplikasi e-APBS, digunakan pendekatan model kesuksesan implementasi DeLone dan McLean. Indikator kesuksesan implementasi sistem menurut DeLone dan McLean meliputi kualitas sistem, kualitas informasi, kualitas layanan, tingkat penggunaan, kepuasan pengguna, dan manfaat bersih. Indikator yang tidak diukur dalam penelitian ini adalah penggunaan, karena aplikasi e-APBS ini merupakan prasyarat wajib untuk terwujudnya tata kelola keuangan yang semakin handal untuk meningkatkan pelayanan publik melalui transparansi, akuntabilitas, partisipasi dan keterbukaan dalam penyusunan perencanaan dan penganggaran di sekolah, sehingga harus digunakan. Penelitian ini mengadopsi penelitian deskriptif, dengan jumlah sampel 80 responden yang diambil dari operator bendahara aplikasi e-APBS. Metode pengumpulan data mengunakan kuesioner, dan menerapkan analisis analisis regresi untuk menganalisis data yang dikumpulkan oleh peneliti. Hasil penelitian menunjukkan bahwa faktor-faktor yang menentukan kesuksesan implementasi aplikasi e-APBS jika dilihat dari dimensi kepuasan pengguna adalah kualitas informasi dan kualitas layanan, dimensi penggunaan adalah kualitas sistem, dan dimensi manfaat bersih (net benefit) adalah kepuasan pengguna.
\end{abstract}

Kata kunci: Model Delone dan McLean, e-APBS.

\section{Pendahuluan}

Pembiayaan merupakan komponen yang penting dalam penyelenggaraan pendidikan. Pembiayaan merupakan unsur yang multak harus tersedia. Tanpa biaya, pendidikan tidak dapat berjalan, dan pembiayaan dibutuhkan sebagai penunjang untuk memaksimalkan segala aspek dan sumber daya pada proses pembelajarn dalam rangka mencapai tujuan pendidikan.

Pada semua tingkatan penyelenggaraan pendidikan, pembiayaan merupakan hal yang sangat penting guna menjamin terlaksananya pendidikan. Pendidikan tidak akan berjalan tanpa adanya biaya. Oleh karena itu, manajemen keuangan pendidikan yang baik menjadi salah satu kunci penunjang keberhasilan tujuan pendidikan.
Terdapat tiga persoalan pokok dalam manajemen keuangan pendidikan, yaitu: (a) financing, yang menyangkut dari mana sumber pembiayaan diperoleh, (b) budgeting, bagaimana dana pendidikan dialokasikan, dan (c) accountability, bagaimana anggaran yang diperoleh digunakan dan dipertanggungjawabkan (Hasbullah 2010).

Setiap tahun sekolah wajib menyusun Anggaran Pendapatan dan Belanja Sekolah (RAPBS) yang menunjukkan bagaimana perencanaan pendapatan dan penggunaan biaya untuk keperluan operasional sekolah. Penggunaan biaya tersebut menggambarkan pola pembiayaan dalam pendidikan.

Dinas Pendidikan Kota Pekalongan telah mengembangkan aplikasi anggaran pendapatan 
dan belanja sekolah (e-APBS). Aplikasi anggaran pendapatan dan belanja sekolah (e-APBS) merupakan aplikasi yang digunakan untuk mengelola anggaran pendapatan dan belanja sekolah dari tingkat sekolah dasar (SD) dan tingkat sekolah menengah pertama (SMP) di Kota Pekalongan.

Keberhasilan implementasi sebuah sistem informasi dapat diadopsi dari model kesuksesan sistem informasi D \& $\mathrm{M}$ (DeLone, W. H. dan Ephraim R. McLean 2003). Berdasarkan model kesuksesan sistem informasi D\&M menyebutkan bahwa kesuksesan implementasi sistem informasi dapat dilihat dari enam faktor yaitu : kualitas sistem, kualitas informasi, kualitas layanan, penggunaan, kepuasan pengguna dan manfaat bersih. Kualitas sistem digunakan untuk mengukur kualitas sistem teknologi informasi. Kualitas informasi yang digunakan untuk mengukur kualitas output dari sistem informasi. Kualitas layanan menunjukkan pelayanan yang diberikan oleh pengembang sistem informasi. Penggunaan merupakan penggunaan output suatu sistem oleh penerima atau penggunaan dan minat memakai sebagai alternatif penggunaan. Kepuasan pengguna merupakan respon penggunaan terhadap penggunaan output sistem informasi. Manfaat bersih adalah efek informasi terhadap perilaku penggunaan dan pengaruh dari informasi terhadap kinerja orgnisasi guna meningkatkan pengetahuan dan efektivitas komunikasi (DeLone, W. H. dan Ephraim R. McLean 2003).

Telah banyak penelitian empiris yang dilakukan untuk mengukur kesuksesan sistem informasi dengan menggunakan model D \& $\mathrm{M}$. Penelitian Jumardi et al melakukan penelitian tentang kesuksesan implementasi sistem informasi skripsi. Penelitian tersebut menggunakan lima variabel yaitu kualitas sistem, kualitas informasi kualitas layanan, kepuasan pengguna dan net benefit. Hasil penelitian menyimpulkan kepuasan pengguna dipengaruhi oleh kualitas informasi dan kualitas sistem. Net benefit dipengaruhi oleh kepuasan pengguna sedangkan kualitas layanan tidak mempunyai pengaruh terhadap kepuasan pengguna (Jumardi R 2015).

Merujuk pada penelitian tersebut penelitian ini dilakukan untuk mengukur kesuksesan implementasi apliaksi e-APBS. Rumusan masalah penelitian ini adalah 1). Apakah kualitas sistem, kualitas informasi, dan kualitas layanan berpengaruh positif dan signifikan terhadap kepuasan pengguna sistem e-APBS? 2). Apakah kualitas sistem, kualitas informasi, dan kualitas layanan berpengaruh positif dan signifikan terhadap penggunaan sistem e-APBS? 3). Apakah penggunaan, kepuasan pengguna berpengaruh positif dan signifikan terhadap manfaat bersih sistem e-APBS?. Manfaat yang didapat dalam penelitian ini yaitu: 1). Dapat memberikan masukan kepada peneliti untuk dapat digunakan sebagai bahan acuan untuk penelitian selanjutnya, 2). Memberikan informasi tentang kesuksesan implementasi aplikasi e-APBS pada Dinas Pendidikan Kota Pekalongan, 3). Memberikan manfaat bagi Dinas Pendidikan Kota Pekalongan untuk lebiih meningkatkan kepuasan pengguna, 4). Sebagai bahan masukan kepada pihak pengembang agar aplikasi yang digunakan selalu memenuhi harapan penggunanya.

\section{Metode Penelitian}

\subsection{Metode Pengumpulan Data}

Data yang digunakan dalam penelitian ini adalah data primer dan data yang telah diolah, disimpan, disajikan dalam format atau bentuk tertentu oleh pihak tertentu untuk kepentingan tertentu (Abdillah 2018).

Teknik pengumpullan data yang digunakan dalam penelitian ini adalah : 1). Observasi yaitu dengan melakukan pengamatan langsung terhadap aplikasi eAPBS. 2).Wawancara yaitu melakukan tanya jawab terkait sistem kepada pengguna sistem. 3). Studi Pustaka yaitu melakukan pengumpulan data dan informasi berdasarkan sumber terkait seperti buku dan jurnal penelitian. 4). Kuesioner yaitu menyebarkan kuesioner yang didalamnya terdapat 22 pertanyaan yang diberikan kepada 80 responden operator e-APBS untuk sekolah tingkat SD dan SMP di Kota Pekalongan. Kuesioner ini berbentuk kuesioner online melalui google form. 


\subsection{Variabel Operasional}

Variabel penelitian meliputi variabel dependen atau endogen adalah variabel yang dipengaruhi atau yang menjadi akibat karena adanya variabel independen. Variabel endogen dalam penelitian ini adalah manfaat bersih. Manfaat bersih merupakan keuntungan yang dirasakan oleh individu dan juga organisasi setelah menerapkan sistem informasi. Indikator yang digunakan untuk menilai manfaat bersih yaitu kecepatan menyelesaikan pekerjaan, kinerja individu dalam menyelesaikan pekerjaan, keefektifan, kemudahan pekerjaan, dan kegunaan dalam pekerjaan.

Kepuasan pengguna sistem merupakan respon dan umpan balik yang dimunculkan setelah menggunakan sistem informasi. Indikator dari kepuasan pengguna meliputi penilaian atas kepuasan data dan informasi, dan penilaian atas kepuasan sistem.

Penggunaan merupakan penggunaan sistem itu sendiri. Indikator untuk menilai penggunaan yaitu frekuensi penggunaan, dan tujuan penggunaan.

Variabel independen atau variabel eksogen adalah variabel yang mempengaruhi variabel dependen atau variabel endogen. Variabel independen atau variabel eksogen dalam penelitian ini adalah kualitas sistem, kualitas informasi, kualitas layanan. Kualitas sistem menunjukkan bagaimana performa aplikasi e-APBS dalam melakukan proses pengolahan informasinya. Indikator kualitas sistem yaitu fleksibiltas sistem, ketersediaan sistem, kekinian, keandalan sistem, kemudahan menggunakan. Kualitas informasi merupakan semua bentuk atau laporan yang dihasilkan aplikasi e-APBS. Indikator kualitas informasi meliputi kelengkapan, ketepatan, keandalan, dan relevansi. Kualitas layanan adalah sebuah perbandingan dari harapan pelanggan dengan persepsi dari layanan nyata yang mereka terima. Indikator yang digunakan untuk menilai kualitas layanan, yaitu jaminan kualitas yang diberikan sistem, kepedulian atau empati sistem terhadap pengguna sistem, kualitas respon sistem terhadap aksi yang dilakukan oleh pengguna.

\subsection{Pengujian Validitas dan Reliabilitas}

Uji validitas untuk mengukur valid tidaknya kuesioner yang digunakan. Untuk menentukan kevalidan dari masing-masing item dalam kueisoner dilakukan dengan menggunakan rumus korelasi sederhana atau pearson product moment. Kriteria keputusan sebuah butir pertanyaan dikatakan valid jika koefisien korelasi product moment melebihi 0.3. Keputusan sebuah item pertanyaan dikatakan valid jika koefisien korelasi product moment melebihi 0.3 (Sugiyono 2017). Sedangkan pengujian reliabilitas digunakan untuk mengetahui tingkat keandalan dari tiap pertanyaan pada kuesioner. Dalam penelitian ini uji reliabilitas menggunakan Cronbach's Alpha. Menurut (Ghozali 2011) suatu konstruk atau variabel dikatakan reliabel jika nilai Cronbach's Alpha $>0.6$.

\section{Hasil dan Pembahasan}

\subsection{Hasil Uji Validitas dan Reliabilitas} Uji Validitas

Uji validitas dilakukan dengan menggunakan Pearson Product Moment. Hasil pengujian validitas dapat disajikan dalam tabel 1.

\section{Tabel 1. Hasil Uji Validitas}

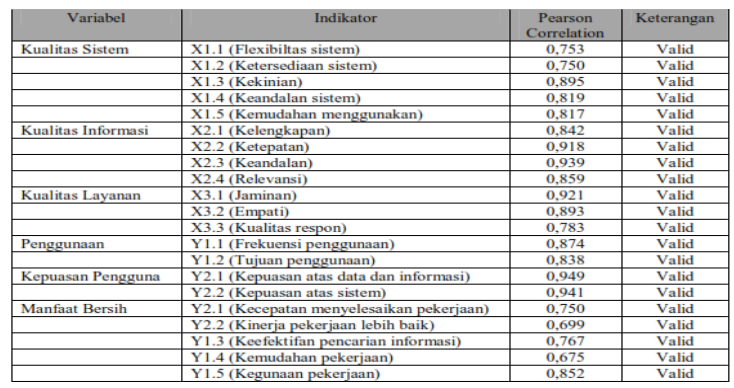

Berdasarkan hasil uji validitas, semua item pertanyaan yang digunakan sebagai pengukuran kesuksesan implementasi sistem memperoleh nilai pearson correlation $>0.3$, ini artinya semua item pertanyaan dari variabel kualitas sistem, kualitas informasi, kualitas layanan dan kepuasan pengguna dalam penelitian ini dinyatakan valid. 


\section{Uji Relibilitas}

Uji reliabilitas dilakukan dengan menggunakan Cronbach's Alpha. Hasil pengujian reliabiltas dapat disajikan dalam tabel 2.

Tabel 2. Hasil Uji Reliabilitas

\begin{tabular}{|l|c|l|}
\multicolumn{1}{|c|}{ Varlabel } & $\begin{array}{c}\text { Cronbach's } \\
\text { Alpha }\end{array}$ & Keterangan \\
\hline Kualitas Sistem & 0.867 & Reliabel \\
\hline Kualitas Informasi & 0.913 & Reliabel \\
\hline Kualitas Layanan & 0.831 & Reliabel \\
\hline Penggunaan & 0,869 & Reliabel \\
\hline Kepuasan Pengguna & 0.880 & Reliabel \\
\hline Manfaat Bersih & 0,919 & Reliabel \\
\hline
\end{tabular}

Berdasarkan tabel 2 diatas, semua variabel yang digunakan dalam pengukuran kesuksesan implementasi aplikasi a-APBS, yaitu kualitas sistem, kualitas informasi, kualitas layanan, penggunaan, kepuasan pengguna, dan manfaat bersih diperoleh nilai Cronbach's Alpha $>0.6$, ini artinya alat ukur yang digunakan untuk mengukur variabel penelitian dinyatakan reliabel.

\subsection{Hasil Uji Hipotesis}

Setelah dilakukan uji validitas dan reliabilitas, langkah selanjutnya analisis regresi. Hasil pengujian hipotesis adalah sebagai berikut :

1. Hasil Uji Hipotesis 1

Uji hipotesis $1\left(\mathrm{H}_{1}\right)$ menyatakan apakah kualitas sistem, kualitas informasi, dan kualitas layanan akan berpengaruh dan signifikan terhadap kepuasan pengguna. Hasil dari uji $\mathrm{H}_{1}$ dapat dilihat pada tabel 3 dan 4 berikut :

Tabel 3. Anova ${ }^{a}$

\begin{tabular}{|ll|r|r|r|r|r|}
\hline \multicolumn{1}{|c|}{ Model } & Sum of Squares & $\mathrm{df}$ & Mean Square & F & Sig. \\
\hline $\mathrm{I}$ & Regression & 115.975 & 3 & 38.658 & 73.612 & $.000^{\mathrm{b}}$ \\
& Residual & 39.913 & 76 & .525 & & \\
& Total & 155.888 & 79 & & & \\
\hline
\end{tabular}

a. Dependent Variable: Kepuasan Pengguna

b. Predictors: (Constant), Kualitas Layanan, Kualitas Sistem, Kualitas Informas

Uji F dapat dilihat dari tabel 3, dimaksudkan untuk mengetahui pengaruh variabel dependen dengan variabel independen. Untuk uji F di dapat nilai sig
$0.000<0.05$, maka dinyatakan signifikan (menolak H0), artinya secara simultan terdapat pengaruh positif antara variabel $\mathrm{Y}$ (kepuasan pengguna) dengan variabel $\mathrm{X}_{1}$ (kualitas sistem), $\mathrm{X}_{2}$ (kualitas informasi), $\mathrm{X}_{3}$ (kualitas layanan).

Tabel 4. Coefficient

\begin{tabular}{|c|c|c|c|c|c|c|}
\hline \multirow{2}{*}{\multicolumn{2}{|c|}{ Model }} & \multicolumn{2}{|c|}{$\begin{array}{c}\text { Unstandardized } \\
\text { Coefficients }\end{array}$} & \multirow{2}{*}{$\begin{array}{c}\begin{array}{c}\text { Standardized } \\
\text { Coefficients }\end{array} \\
\text { Beta }\end{array}$} & \multirow[b]{2}{*}{$\mathrm{t}$} & \multirow[b]{2}{*}{ Sig. } \\
\hline & & B & Std. Error & & & \\
\hline \multirow[t]{4}{*}{1} & (Constant) & -.772 & .840 & & -.919 & .361 \\
\hline & Kualitas Sistem & .020 & .067 & .033 & -302 & .763 \\
\hline & Kualitas Informasi & .236 & .075 & .408 & 3.159 & .002 \\
\hline & Kualitas Layanan & .430 & .104 & -.513 & 4.154 & .000 \\
\hline
\end{tabular}

Untuk uji t dapat dilihat pada tabel 4 , bahwa $\mathrm{X}_{1}$ (kualitas sistem), didapat nilai sig $0.763>0.05$, maka dinyatakan tidak signifikan (menerima $\mathrm{H} 0$ ), artinya secara parsial variabel $X_{1}$ tidak berpengaruh terhadap variabel $\mathrm{Y}$. Untuk uji $\mathrm{t} \mathrm{X}_{2}$ (kualitas informasi), di dapat nilai sig $0.002<$ 0.05 , maka dinyatakan signifikan (menolak $\mathrm{H} 0$ ), artinya secara parsial variabel $\mathrm{X}_{2}$ berpengaruh terhadap variabel $\mathrm{Y}$. Untuk uji $\mathrm{t} \mathrm{X}_{3}$ (kualitas layanan), didapat nilai sig $0.000<0.05$, maka dinyatakan signifikan (Menolak H0), artinya secara parsial variabel $\mathrm{X}_{3}$ berpengaruh terhadap variabel Y.

\section{Hasil Uji Hipotesis 2}

Uji hipotesis $2\left(\mathrm{H}_{2}\right)$ menyatakan apakah kualitas sistem, kualitas informasi, dan kualitas layanan akan berpengaruh dan signifikan terhadap intensitas penggunaan. Hasil dari uji $\mathrm{H}_{2}$ dapat dilihat pada tabel 5 dan 6 berikut :

Tabel 5. Anova ${ }^{\mathrm{a}}$

\begin{tabular}{|c|c|c|c|c|c|c|}
\hline \multicolumn{2}{|c|}{ Model } & Sum of Squares & $\mathrm{df}$ & Mean Square & $\bar{F}$ & Sig. \\
\hline 1 & Regression & 75.240 & 3 & \multirow{3}{*}{$\begin{array}{r}25.080 \\
.876\end{array}$} & \multirow[t]{3}{*}{28.572} & \multirow[t]{3}{*}{$.000^{b}$} \\
\hline & Residual & 66.710 & 76 & & & \\
\hline & Total & 141.950 & 79 & & & \\
\hline
\end{tabular}

b. Predictors: (Constant), Kualitas Layanan, Kualitas Sistem, Kualitas Informasi

Uji F dapat dilihat dari tabel 5, dimaksudkan untuk mengetahui pengaruh variabel dependen dengan variabel independen. Untuk uji $\mathrm{F}$ di dapat nilai sig $0.000<0.05$, maka dinyatakan signifikan (menolak H0), artinya secara simultan terdapat pengaruh positif antara variabel $\mathrm{Y}$ (intensitas penggunaan) dengan variabel $X_{1}$ (kualitas sistem), $\mathrm{X}_{2}$ (kualitas informasi), $\mathrm{X}_{3}$ (kualitas layanan). 
Tabel 6. Coefficient

\begin{tabular}{|c|c|c|c|c|c|c|}
\hline \multirow{2}{*}{\multicolumn{2}{|c|}{ Model }} & \multicolumn{2}{|c|}{$\begin{array}{l}\text { Unstandardized } \\
\text { Coefficients }\end{array}$} & \multirow{2}{*}{$\begin{array}{c}\begin{array}{c}\text { Standardized } \\
\text { Coefficients }\end{array} \\
\text { Beta }\end{array}$} & \multirow[b]{2}{*}{ t } & \multirow[b]{2}{*}{ Sig. } \\
\hline & & B & Std. Error & & & \\
\hline \multirow[t]{4}{*}{1} & (Constant) & -654 & 1.085 & & -.603 & .548 \\
\hline & Kualitas Sistem & .215 & .086 & .373 & 2.492 & .015 \\
\hline & Kualitas Informasi & -.046 & 097 & -.083 & -.475 & .636 \\
\hline & Kualitas Layanan & .375 & 134 & .469 & .469 & .006 \\
\hline
\end{tabular}

Untuk uji $\mathrm{t}$ dapat dilihat pada tabel 6 , bahwa $\mathrm{X}_{1}$ (kualitas sistem), didapat nilai sig $0.015<0.05$, maka dinyatakan signifikan (menerima $\mathrm{H} 0$ ), artinya secara parsial variabel $\mathrm{X}_{1}$ berpengaruh terhadap variabel $\mathrm{Y}$. Untuk uji $\mathrm{t} \mathrm{X}_{2}$ (kualitas informasi), di dapat nilai sig $0.639>0.05$, maka dinyatakan tidak signifikan (menerima H0), artinya secara parsial variabel $\mathrm{X}_{2}$ tidak berpengaruh terhadap variabel $\mathrm{Y}$. Untuk uji t $\mathrm{X}_{3}$ (kualitas layanan), didapat nilai sig $0.006<0.05$, maka dinyatakan signifikan (menerima H0), artinya secara parsial variabel $\mathrm{X}_{3}$ berpengaruh terhadap variabel Y.

\section{Hasil Uji Hipotesis 3}

Uji hipotesis $3\left(\mathrm{H}_{3}\right)$ menyatakan apakah intensitas penggunaan, dan kepuasan pengguna akan berpengaruh dan signifikan terhadap manfaat bersih. Hasil dari uji $\mathrm{H}_{3}$ dapat dilihat pada tabel 7 dan 8 berikut :

Tabel 7. Anova ${ }^{a}$

\begin{tabular}{|c|c|c|c|c|c|}
\hline Model & Sum of Squares & $\mathrm{df}$ & Mean Square & $\mathrm{F}$ & Sig. \\
\hline Regression & 471.632 & 2 & 235.816 & 96.498 & $.000^{b}$ \\
\hline Residual & 188.168 & 77 & 2.444 & & \\
\hline Total & 659,800 & 79 & & & \\
\hline
\end{tabular}

a. Dependent Variable: Manfaat Bersih

b. Predictors: (Constant), Kepuasan Pengguna, Penggunaan

Uji F dapat dilihat dari tabel 7, dimaksudkan untuk mengetahui pengaruh variabel dependen dengan variabel independen. Untuk uji $\mathrm{F}$ di dapat nilai sig $0.000<0.05$, maka dinyatakan signifikan (menolak H0), artinya secara simultan terdapat pengaruh positif antara variabel $\mathrm{Y}$ (manfaat bersih) dengan variabel $\mathrm{X}_{1}$ (penggunaan), $\mathrm{X}_{2}$ (kepuasan pengguna).
Tabel 8. Coefficient

\begin{tabular}{|c|c|c|c|c|c|c|}
\hline \multirow[b]{2}{*}{ Model } & & \multicolumn{2}{|c|}{ Unstandardized Coefficients } & \multirow{2}{*}{$\begin{array}{c}\begin{array}{c}\text { Standardized } \\
\text { Coefficients }\end{array} \\
\text { Beta } \\
\end{array}$} & \multirow[b]{2}{*}{$\mathrm{t}$} & \multirow[b]{2}{*}{ Sig. } \\
\hline & & $\mathrm{B}$ & Std. Error & & & \\
\hline 1 & (Constant) & 6.593 & 1.235 & & 5.340 & .000 \\
\hline & Penggunaan & .304 & .168 & .141 & 1.805 & .075 \\
\hline & Kepuasan Pengguna & 1.543 & .161 & .750 & 9.607 & .000 \\
\hline
\end{tabular}

Untuk uji t dapat dilihat pada tabel 9, bahwa $\mathrm{X}_{1}$ (penggunaan), didapat nilai sig $0.075>0.05$, maka dinyatakan tidak signifikan (menerima $\mathrm{H} 0$ ), artinya secara parsial variabel $X_{1}$ tidak berpengaruh terhadap variabel $\mathrm{Y}$. Untuk uji t $\mathrm{X}_{2}$ (kepuasan pengguna), di dapat nilai sig $0.000<$ 0.05, maka dinyatakan signifikan (menolak H0), artinya secara parsial variabel $\mathrm{X}_{2}$ berpengaruh terhadap variabel $\mathrm{Y}$.

\section{Kesimpulan dan Saran}

Berdasarkan hasil pengujian hipotesis untuk mengukur kesuksesan implementasi aplikasi eAPBS dapat disimpulkan sebagai berikut :

1. Uji $\mathrm{F}$ dari hipotesis 1 diperoleh hasil bahwa kualitas sistem, kualitas informasi, dan kualitas layanan berpengaruh dan signifikan terhadap kepuasan pengguna.

2. Uji $\mathrm{F}$ dari hipotesis 2 diperoleh hasil bahwa kualitas sistem, kualitas informasi, dan kualitas layanan berpengaruh dan signifikan terhadap penggunaan.

3. Uji F dari hipotesis 3 diperoleh hasil bahwa penggunaan, dan kepuasan pengguna berpengaruh dan signifikan terhadap manfaat bersih.

4. Uji t dari ke 3 hipotesis diperoleh hasil bahwa kualitas informasi, kualitas layanan berpengaruh dan signifikan terhadap kepuasan pengguna, kualitas sistem berpengaruh dan signifikan terhadap penggunaan, sedangkan kepuasan pengguna berpengaruh pada manfaat bersih.

5. Faktor - faktor yang menentukan kesuksesan implementasi aplikasi e-APBS jika dilihat dari dimensi kepuasan pengguna adalah kualitas informasi dan kualitas layanan, dimensi penggunaan adalah kualitas sistem, dan dimensi manfaat bersih adalah kepuasan pengguna. 


\section{DAFTAR PUSTAKA}

Abdillah, W. Metode Penelitian Terpadu Sistem Informasi - Pemodelan Teoritis, Pengukuran, dan Pengujian Statistika, 1st Ed. Yogyakarta: Andi Offset, 2018.

DeLone, W. H. dan Ephraim R. McLean. "The DeLone and McLean Model of Information Systems Success: A Ten Year Update." Journal of Management Information Systems/Spring, 2003: vol. 19. No. 4, p. $9-30$.

DeLone, W.H. and E.R.Mc Lean. Information System Success: The Quest for the Dependent Variable Infomation System Research 3 (March). 1992.

Ghozali, Imam. Aplikasi Analisis Multivariate Dengan Program SPSS. Semarang: Badan Penerbit Universitas Diponegoro, 2011.

Hasbullah. Otonomi Pendidikan: Kebijakan Otonomi Daerah Dan Implikasinya Terhadap. Jakarta: Rajawali Pers, 2010.

IJumardi R, Nugroho E dan Hidayah I. Analisis Kesuksesan Implementasi Sistem Informasi Skripsi Pada Program Studi Teknik Informatika Universitas Pembangunan Nasional "Veteran". Yogyakarta: Seminar Nasional Aplikasi Teknologi Informasi, 2015.
Livary, Juhani. "An Empirical Test of The DeLone-McLean Model of Information System Success, Dataabase for Advance in Information System (DFA)." ProQuest Company Volume 36 ISSN: 1532-0936, 2005.

Machmud, Rizan. Kepuasan Pengguna Informasi (Studi Kasus pada T3-Online. Kota Gorontalo: Ideas Publishing, 2018.

Restuningdiah, Nurika dan Nur Indriantoro. Pengaruh Partisipasi terhadap Kepuasan Pemakai dalam Pengembangan Sistem Informasi dengan Kompleksitas Tugas, Kompleksitas Sistem, dan Pengaruh Pemakai sebagai Moderating Variable. Jurnal Riset Akuntansi Indonesia, Vol.3, No.2, 2000.

Sugiyono. Metode Penelitian Kuantitatif, Kualitatif, dan R\&D. Bandung: CV Alfabeta, 2017.

Tordace.W.J, McKens D.J g. "The Relationship Of User Participation and User Satisfation: An Investigatio Of ForUR Contingency Factis." Miss Quarthy, 1994. 